\title{
Secretion Mechanism of Bacillus subtilis Levansucrase: Characterization of the Second Step
}

\author{
By RÉGIS CHAMBERT* ANd MARIE-FRANÇOISE PETIT-GLATRON \\ Institut Jacques Monod, CNRS-Université Paris VII, Laboratoire Génétique et Membranes, \\ 2 place Jussieu, 75251 Paris Cedex 05, France
}

(Received 14 October 1987)

The kinetics of levansucrase secretion were examined in a strain of Bacillus subtilis which overproduces the enzyme $\left(\mathrm{sac}^{\mathrm{h}}\right)$. Pulse-labelling experiments indicated that the second step of the levansucrase secretion process has the properties of a membrane active-transport system. This event appears to be directly linked to the influx of iron into the bacteria. The response of $B$. subtilis to the inducer of levansucrase synthesis was modulated by ferrichelators and the extent of the response varied with the nature of the ferrichelator. Ferridihydroxybenzoate markedly shortened the induction lag period. It is inferred from these data that iron occurs as a cofactor for components of the membrane sites of synthesis/secretion of $B$. subtilis levansucrase.

\section{INTRODUCTION}

It has recently been shown that in the levansucrase-overproducing strain QB112 ( $\left.\mathrm{sac}^{\mathrm{h}}\right)$ of

Bacillus subtilis, translocation of levansucrase across the membrane occurs via a two-step mechanism involving the proteolytic processing of a $53000 M_{\mathrm{r}}$ membrane precursor form of the enzyme and secretion of the resulting $50000 M_{\mathrm{r}}$ membrane form (Petit-Glatron et al., 1987). Multistep mechanisms for protein translocation have been demonstrated in other prokaryotic systems (Rothman \& Kornberg, 1986; Freudl et al., 1986) and have been postulated to be generally involved in protein translocation (Wickner \& Lodish, 1985). However, little is known of the second step in the secretion process, which is generally believed to be a folding step occurring on the outside of the membrane surface. Himeno et al. (1986) recently demonstrated that protein secretion in $B$. subtilis was influenced by both the signal sequence and the following mature portion of the exported protein. Moreover, the role of the signal sequence is now uncertain, as the experiments of Smith et al. (1987) demonstrated that random regions of $B$. subtilis chromosomal DNA may function as export signals in Escherichia coli and B. subtilis.

These findings support the hypothesis of a discrete step in the export pathway, triggered by the mature form of the protein, in which the presumed $B$. subtilis export machinery should play a role. We have shown that partially purified preparations of both transient membrane levansucrase forms display enzyme activity only in the presence of complexed ferric iron (PetitGlatron et al., 1987). Such data are intriguing since the crystalline purified exocellular form is not associated with iron (Lebrun \& Van Rapenbusch, 1980). However, iron has been shown to increase the thermostability of exocellular levansucrase and to cause its tetramerization (Delobbe, 1968). In the present study we used pulse-labelling experiments to examine the second step of the proposed mechanism. Particular attention was paid to the possible role of iron in this step and in the overall production of levansucrase.

Abbreviations: CCCP, carbonyl cyanide $m$-chlorophenylhydrazone; DHB, 2,3-dihydroxybenzoate. 


\section{METHODS}

Strain and culture conditions. The derivative strain QB112(sacU $\left.\mathrm{H}^{\mathrm{h}}\right)$ of the wild-type Bacillus subtilis $168 \mathrm{Marburg}$ (Kunst et al., 1974) was grown at $37^{\circ} \mathrm{C}$ in the medium previously described (Petit-Glatron et al., 1980). The carbon source was glucose $\left(10 \mathrm{~g} \mathrm{t}^{-1}\right)$. One optical density unit of cell suspension at $650 \mathrm{~nm}\left(\mathrm{OD}_{650}\right)$ corresponded to $1.4 \times 10^{8}$ cells $\mathrm{ml}^{-1}$ and $80 \mu \mathrm{g}$ protein $\mathrm{ml}^{-1}$, estimated according to Bradford (1976). The medium usually contained ferric ammonium citrate as iron source $\left(22 \mu \mathrm{g} \mathrm{ml}^{-1}\right)$. The ferric ammonium citrate was omitted from iron-deficient medium.

Gel electrophoresis and immunoblotting. Proteins were analysed on $10 \%$ (w/v) SDS-polyacrylamide gels. Electrophoresis was done in a slab-gel apparatus using the discontinuous system described by Laemmli (1970). Immunoblotting on nitrocellulose sheets $(0.45 \mu \mathrm{m}$ pore size), in $25 \mathrm{mM}$ - Tris/ $\mathrm{HCl} \mathrm{pH} 8.3,192 \mathrm{~mm}$-glycine, $20 \%$ $(\mathrm{v} / \mathrm{v})$ methanol and $0.02 \%$ SDS, was carried out using a constant current of $400 \mathrm{~mA}$ for $2 \mathrm{~h}$. Incubation with purified rabbit anti-levansucrase antibodies and radio-iodinated protein A was adapted from Burnette (1981) as described previously (Benyahia \& Petit-Glatron, 1985).

Preparation and purification of antibodies. Levansucrase was prepared from the culture supernatant of an induced culture of QB112 according to the procedure of Dedonder (1966). Antibodies against pure exocellular levansucrase were raised in rabbits. Levansucrase was covalently coupled to glutaraldehyde activated Ultrogel (Act Ultrogel AcA 22, IBF) and the antibodies were purified by affinity chromatography (Avrameas \& Ternynk, 1969).

Pulse-labelling experiments. Cells of $B$. subtilis QB112 induced by sucrose ( $50 \mathrm{~mm}$ final concentration) at an $\mathrm{OD}_{650}$ of 1 for $1 \mathrm{~h}$ were pulse-labelled by adding $1 \mathrm{mCi}(37 \mathrm{MBq})\left[{ }^{35}\right.$ S $]$ methionine $\left(800 \mathrm{Ci} \mathrm{mmol}^{-1}\right)$ to $10 \mathrm{ml}$ culture suspension, maintained at $37^{\circ} \mathrm{C}$. After a pulse period of $30 \mathrm{~s}$, non-radioactive methionine (final concentration $2 \mathrm{mM}$ ) was added. Samples were removed at intervals and all reactions were stopped by diluting the samples fivefold with ice-cold stopping buffer [0.1 M-phosphate buffer $\mathrm{pH} 7$, containing $2 \mathrm{M}-\mathrm{KCl}, 200 \mu \mathrm{g}$ chloramphenicol ml-1, $5 \mathrm{mM}$-EDTA and $0.2 \mathrm{mM}$-phenylmethylsulphonyl fluoride (PMSF)].

The cell suspensions were centrifuged and the supernatants were dialysed at $4{ }^{\circ} \mathrm{C}$ against $5 \mathrm{mM}-\mathrm{Tris} / \mathrm{HCl}$ buffer pH 6.8. The dialysed supernatant samples were lyophilized and resuspended in $2 \%(\mathrm{w} / \mathrm{v})$ SDS and $10 \%(\mathrm{v} / \mathrm{v})$ glycerol (final concentration) for electrophoretic analysis.

The bacterial pellets were washed with cold stopping buffer without $\mathrm{KCl}$ and resuspended in $0.5 \mathrm{M}-\mathrm{Tris} / \mathrm{HCl}$ buffer $\mathrm{pH} 7$ containing $5 \mathrm{~mm}$-EDTA, $20 \mathrm{~mm}$-PMSF and $1 \%$ SDS. The cells were disrupted by sonication and the suspensions were incubated for $5 \mathrm{~min}$ at $95^{\circ} \mathrm{C}$ and centrifuged for $20 \mathrm{~min}$ at $10000 \mathrm{~g}$. Supernatants from this

step $(1 \mathrm{ml})$ were diluted fivefold in TNET $(50 \mathrm{~mm}-\mathrm{Tris} / \mathrm{HCl} \mathrm{pH} 8$ containing $150 \mathrm{~mm}-\mathrm{NaCl}, 5 \mathrm{~mm}-\mathrm{EDT} A$ and $1 \%$ Triton X-100) and preincubated for $30 \mathrm{~min}$ at $20^{\circ} \mathrm{C}$ with $100 \mu \mathrm{l}$ washed immunoprecipitin (BRL). They were then centrifuged for $20 \mathrm{~min}$ at 3000 r.p.m. and the resulting supernatants were incubated overnight with purified anti-levansucrase antibodies $\left(4 \mu \mathrm{g} \mathrm{ml}^{-1}\right)$ at $4{ }^{\circ} \mathrm{C}$. Immunoprecipitin $(100 \mu \mathrm{l})$ was then added and incubation was continued for a further $1 \mathrm{~h}$ at $20^{\circ} \mathrm{C}$. The immunoprecipitates were recovered by centrifugation, the pellets were washed three times with $1 \mathrm{ml}$ of TNET, and finally resuspended in the electrophoresis sample buffer. The samples were boiled for $5 \mathrm{~min}$ and analysed by SDS-PAGE.

Iron uptake. The cells were grown in iron-deficient medium. The concentration of residual iron in the medium, assayed by the method of Tangeras et al. (1980), was less than $1 \mu \mathrm{M}$. Radioactive ferric chloride $\left[50 \mu 1\right.$ of ${ }^{59} \mathrm{FeCl}_{3}$, 3-320 mCi mg $\mathrm{mg}^{-1}, 100 \mu \mathrm{Ci} \mathrm{ml}{ }^{-1}\left(3.7 \mathrm{MBq} \mathrm{ml}^{-1}\right)$ ] was added to give a final iron concentration of $1 \mu \mathrm{M}$. Samples

$(200 \mu \mathrm{l})$ were withdrawn at intervals and filtered through $0.45 \mu \mathrm{m}$ Millipore membranes. The membranes were washed with $10 \mathrm{ml}$ iron-deficient medium, dried, and their radioactivity measured.

Levansucrase activity assay. Levansucrase activity was estimated by measuring the initial rate of the exchange reaction catalysed by the enzyme. One unit of enzyme activity is defined as the amount of enzyme exchanging $1 \mu \mathrm{mol}$ glucose $\mathrm{min}^{-1}$ under the following conditions: $37^{\circ} \mathrm{C}, 0.05 \mathrm{M}$-potassium phosphate $\mathrm{pH} 6,0 \cdot 1 \mathrm{M}$-sucrose and $0 \cdot 2 \mathrm{M}-\left[{ }^{14} \mathrm{C}\right] \mathrm{glucose}$. One unit of enzyme activity corresponds to $38 \mathrm{pmol}(2 \mu \mathrm{g})$ of enzyme (Chambert \& GonzyTréboul, 1976).

Measurements of differential rates of enzyme synthesis. Samples $(0.5 \mathrm{ml})$ of cell suspension were withdrawn at intervals during exponential growth and $0.05 \mathrm{ml}$ of the following mixture was added to each sample: lysozyme $10 \mathrm{mg} \mathrm{ml}^{-1}$, DNAase $0 \cdot 1 \mathrm{mg} \mathrm{ml}^{-1}, \mathrm{MgCl}_{2} 2 \mathrm{mg} \mathrm{ml}^{-1}$; the $\mathrm{pH}$ was adjusted to 6 by addition of $0.05 \mathrm{ml} 2 \mathrm{M}-$ phosphate buffer pH 6. The samples were incubated for $5 \mathrm{~min}$ at $37^{\circ} \mathrm{C}$ and dialysed overnight at $4{ }^{\circ} \mathrm{C}$ against $0.05 \mathrm{M}$-phosphate buffer $\mathrm{pH}$ 6. The levansucrase activity in each suspension of lysed bacteria was assayed.

Preparation of ferrisiderophores. Ferrisiderophores were prepared immediately before use by mixing the appropriate deferrisiderophore with ferric chloride. The ferric chelate of 2,3-dihydroxybenzoate (ferri-DHB) was prepared at a siderophore/iron molar ratio of $3: 1$; ferridesferal was prepared at a siderophore/iron molar ratio of $1: 1$.

Chemicals. Desferal was from Ciba Geigy, DHB from Aldrich. Radioactive compounds were purchased from Amersham. All other chemicals were reagent grade. 


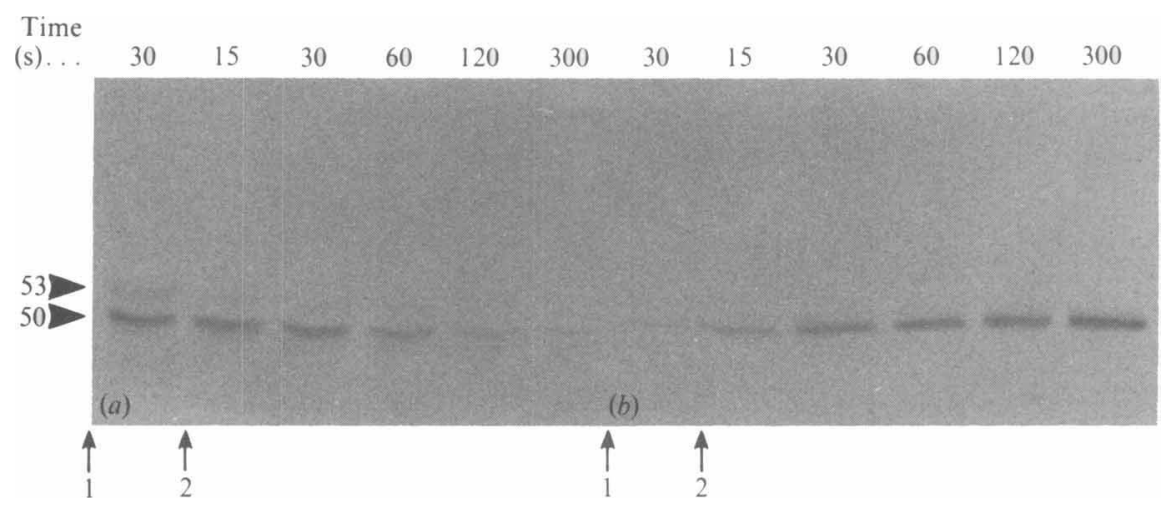

Fig. 1. Synthesis and secretion of the various forms of labelled levansucrase during a pulse-chase experiment. Bacteria in the exponential phase of growth $\left(\mathrm{OD}_{650}=1\right)$ were fully induced with $50 \mathrm{~mm}$ sucrose for $90 \mathrm{~min}$, then labelled for $30 \mathrm{~s}$ with [ $\left.{ }^{35} \mathrm{~S}\right]$ methionine $\left(100 \mu \mathrm{Ci} \mathrm{ml}^{-1}\right)$ and chased with a 5000 fold excess of non-radioactive methionine ( $2 \mathrm{~mm}$ final concentration). Samples $(1 \mathrm{ml})$ were removed at $30 \mathrm{~s}$ of the pulse period, and at 15,30,60,120 and $300 \mathrm{~s}$ of the chase period, and treated and analysed as described in Methods. (a) Labelled levansucrase in immunoprecipitates obtained from lysed bacteria. (b) Labelled levansucrase present in the culture supernatant. Arrows 1 and 2 indicate the beginning of the pulse and chase periods, respectively. The $50000 M_{\mathrm{r}}$ and the $53000 M_{\mathrm{r}}$ forms are indicated by 50 and 53.

\section{RESULTS}

Pulse-labelling experiments confirm the two-step mechanism for levansucrase secretion

We have previously shown the presence of two different transient forms of levansucrase by immunoblot analysis of the membrane fraction of $B$. subtilis QB112 induced for levansucrase synthesis (Petit-Glatron et al., 1987). The half-lives of these species at $37^{\circ} \mathrm{C}$ were $4-5 \mathrm{~s}$ for the $53000 M_{\mathrm{r}}$ form and 32-42 s for the $50000 M_{\mathrm{r}}$ form. Pulse-labelling experiments were used to study the kinetics of the appearance and disappearance of these two forms (Fig. 1). The two transient forms reacting with antibodies directed against levansucrase appeared to be labelled in the induced cells after a short pulse of $\left[{ }^{35} S\right]$ methionine. The $50000 M_{\mathrm{r}}$ form was more abundant than the $53000 M_{\mathrm{r}}$ form after a $30 \mathrm{~s}$ pulse. The labelled $53000 M_{\mathrm{r}}$ form disappeared rapidly after the addition of non-radioactive methionine. The labelled $50000 M_{\mathrm{r}}$ form disappeared more slowly as labelled levansucrase appeared simultaneously in the culture supernatant. As observed previously (Chambert \& Petit-Glatron, 1984), levansucrase was the only exocellular protein expressed in this $B$. subtilis strain.

The two-step mechanism proposed recently (Petit-Glatron et al., 1987) for the secretion process of levansucrase can account for these results. Processing of the $53000 M_{\mathrm{r}}$ membrane form to the $50000 M_{\mathrm{r}}$ membrane form appeared to be faster than conversion of the latter to the exocellular form, leading to an accumulation of labelled $50000 M_{\mathrm{r}}$ membrane form. This delayed labelling reflects the difference between the rates of each step. The existence of a significant pool of the membrane $50000 M_{\mathrm{r}}$ form allowed the second step to be experimentally separated by pulse-chase experiments. The first step was too fast to be quantified but the second step was

examined by quantitative analysis of the chase period (Fig. 2). If $\mathrm{E}_{\mathrm{mb}}^{0}$ is the amount of labelled $50000 M_{\mathrm{r}}$ membrane form present at the beginning of the chase period (time 0 ), and $\mathrm{E}_{\mathrm{mb}}$ is the amount of the same species present at time $t$, and if it is assumed that the rate of disappearance of this form from the cells is proportional to its amount at any time, the following equation describes the kinetics of the disappearance of the 50,000 $M_{\mathrm{r}}$ form during the chase period:

$$
-\frac{\mathrm{dE}_{\mathrm{mb}}}{\mathrm{d} t}=k \mathrm{E}_{\mathrm{mb}}
$$




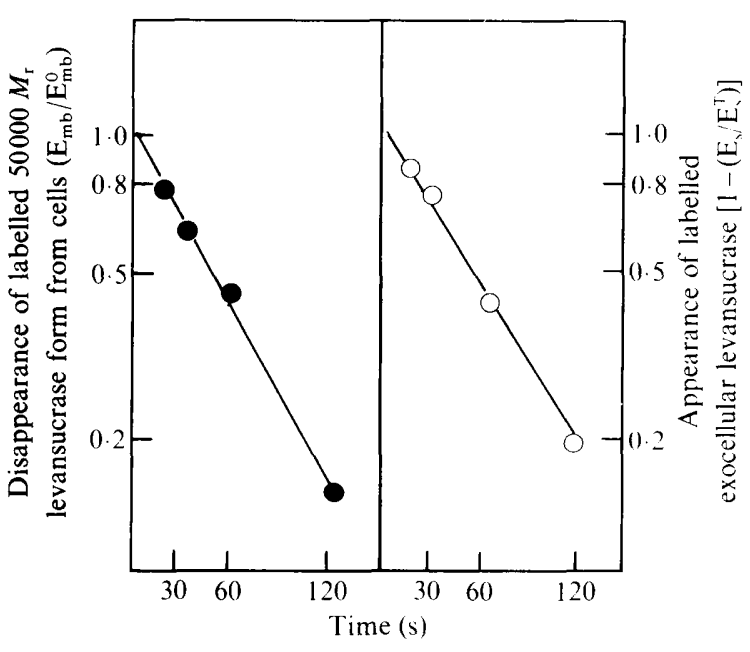

Fig. 2

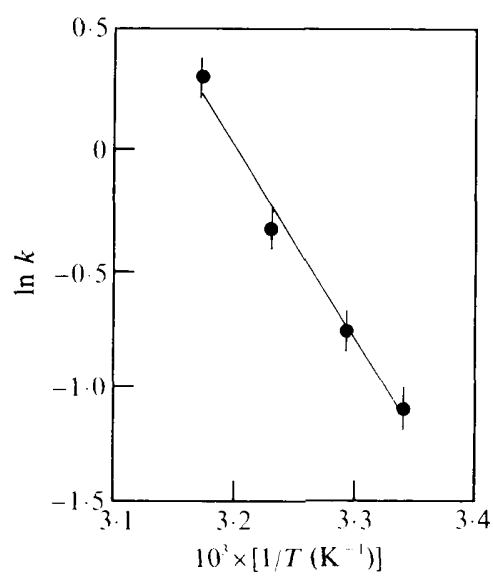

Fig. 3

Fig. 2. Kinetics of the disappearance of labelled $50000 M_{\mathrm{r}}$ levansucrase form from cells $(O)$ and of the appearance of labelled exocellular levansucrase in the culture supernatant $(O)$. Experimental points were obtained by measuring the radioactivity of the spots on the electrophoresis gel shown in Fig. 1. The equations ( 1 and 2 ) used to construct the curves are given in the text.

Fig. 3. Temperature dependence of levansucrase secretion into the culture supernatant. At each temperature, bacteria in the exponential phase of growth $\left(\mathrm{OD}_{650}=1\right)$ were fully induced with $50 \mathrm{~mm}$ sucrose for $90 \mathrm{~min}$, labelled with $\left.{ }^{35} \mathrm{~S}\right]$ methionine for $30 \mathrm{~s}$ and chased with non-radioactive methionine as described for Fig. 1. The rate constant, $k$, of levansucrase secretion was calculated from the kinetics of the appearance of the labelled protein in the culture supernatant as shown in Fig. 2 . The mean value and the standard deviation of four independent assays at each temperature are plotted according to Arrhenius.

then

$$
\ln \frac{\mathrm{E}_{\mathrm{mb}}}{\mathrm{E}_{\mathrm{mb}}^{0}}=-k t
$$

A semi-logarithmic plot of the experimental data showed that the disappearance of the 50000 $M_{\mathrm{r}}$ membrane form followed the pseudo-first-order kinetics postulated. Applying the above equation, the rate constant $(k)$ for the $50000 M_{\mathrm{r}}$ membrane form was found to be $1.4 \times 10^{-2} \mathrm{~min}^{-1}$ and the half-life was $49 \mathrm{~s}$. These values are nearly the same as those obtained previously (Petit-Glatron et al., 1987) by a less accurate method.

The equation for the appearance of labelled levansucrase in the supernatant was established in the same way. If $E_{s}^{\mathrm{T}}$ is the total amount of labelled exocellular form which can be released at $t=\infty$, and $\mathrm{E}_{\mathrm{s}}$ is the amount of the same form released at any time during the chase period, and if the rate of its appearance is assumed to be proportional to the amount of the labelled form which remained associated with the cells, then:

$$
\frac{\mathrm{dE}_{\mathrm{s}}}{\mathrm{d} t}=k\left(\mathrm{E}_{\mathrm{s}}^{\mathrm{T}}-\mathrm{E}_{\mathrm{s}}\right)
$$

and

$$
\ln \left(1-\frac{\mathrm{E}_{\mathrm{s}}}{\mathrm{E}_{\mathrm{s}}^{\mathrm{T}}}\right)=-k t
$$

The rate constant $(k)$ determined from the curve in Fig. 2 is $1.3 \times 10^{-2} \mathrm{~min}^{-1}$ and the half-life $53 \mathrm{~s}$.

The disappearance of the labelled levansucrase from the cells and the appearance of the labelled exocellular form are simultaneous. Thus the kinetics of the second step of levansucrase 
translocation may be readily obtained from the kinetics of the release of labelled levansucrase in the culture supernatant during the chase period.

\section{Evaluation of the energy barrier for the second step of the levansucrase export pathway}

The data obtained from pulse-chase experiments were used to determine the individual rate constant of the second step of levansucrase translocation. The temperature dependence of this kinetic parameter was then established over the growth temperature range, $26-42{ }^{\circ} \mathrm{C}$. The mean and standard deviation of four independent assays at each temperature were plotted according to Arrhenius (Fig. 3), giving a significant straight line from regression adjustment with the leastsquares method. The energy of activation $(E)$ for levansucrase secretion was calculated to be $16 \cdot 5 \pm 1 \mathrm{kcal} \mathrm{mol}^{-1}\left(69 \cdot 0 \pm 4 \mathrm{~kJ} \mathrm{~mol}^{-1}\right)$. While interpretation of an activation thermodynamic parameter in terms of reaction mechanism presents some difficulties, this result may indicate that the second step in the levansucrase secretion pathway is not a simple diffusion process but an active, energy-requiring, process. The nature of the driving force for this process may be revealed by studying the effects of metabolic poisons and membrane-modifying agents.

\section{Effects of metabolic poisons and of ionophores on levansucrase secretion}

The effects of metabolic poisons and of ionophores on the second step were examined by pulse-labelling the cells with radioactive methionine for $30 \mathrm{~s}$ followed by a chase with a nonradioactive methionine solution containing different poisons (Fig. 4). The amounts of labelled levansucrase released into the culture supernatant were evaluated directly by gel electrophoresis as shown in Fig. 1. The kinetics of levansucrase release was established from these data plus the

results obtained from a control experiment conducted without addition of poison during the chase period. The kinetic data shown in Fig. 4 indicate that: (1) the release of labelled levansucrase was independent of protein synthesis, since the kinetics was only slightly affected by the presence of chloramphenicol in the culture medium; (2) the metabolic poisons, cyanide

and arsenate, greatly inhibited levansucrase release; (3) the release was also partially inhibited by the ionophores, valinomycin and carbonyl cyanide $m$-chlorophenylhydrazone (CCCP).

These data may support a possible role for the energized membrane in the second step of levansucrase secretion. However, the results obtained do not distinguish between a direct role of the proton-motive force in the translocation of levansucrase and an indirect role. This indirect role may be the requirement for an energized membrane to keep components of the presumed export machinery in an active conformation or to maintain the movement through the membrane of an unknown molecular species involved directly in the translocation process. Our attention was focused on the latter hypothesis, and especially on the movement of ferric ions, since we have previously shown (Petit-Glatron et al., 1987) that iron may play a role in the folding of the isolated membrane forms of levansucrase.

\section{Effects of metabolic poisons and ionophores on iron uptake by B. subtilis QB112}

Peters \& Warren (1970) have shown that iron uptake by $B$. subtilis occurs by an energydependent active-transport system. The effect on iron uptake of the drugs used above was investigated (Fig. 5). All the drugs tested rapidly and completely inhibited iron uptake. These results may indicate a possible relation between the transport of iron and the translocation of levansucrase. However, the drugs used have drastic effects on the cell physiology since they stop growth and cause lysis (Joliffe et al., 1981). Such effects confuse the interpretation of the results we obtained. We therefore sought a more specific and reversible inhibitor of levansucrase secretion which should also act on iron uptake. In preliminary experiments, EDTA, an efficient chelator of $\mathrm{Fe}^{3+}$, was found to fulfil these requirements, and its effect was studied further.

\section{Effect of EDTA on the growth of B. subtilis QB112 and on levansucrase production in iron-deficient medium}

The cells continued to grow exponentially throughout the experimental period (which did not exceed 1.5 generation times) at the EDTA concentrations studied. The differential rate of 


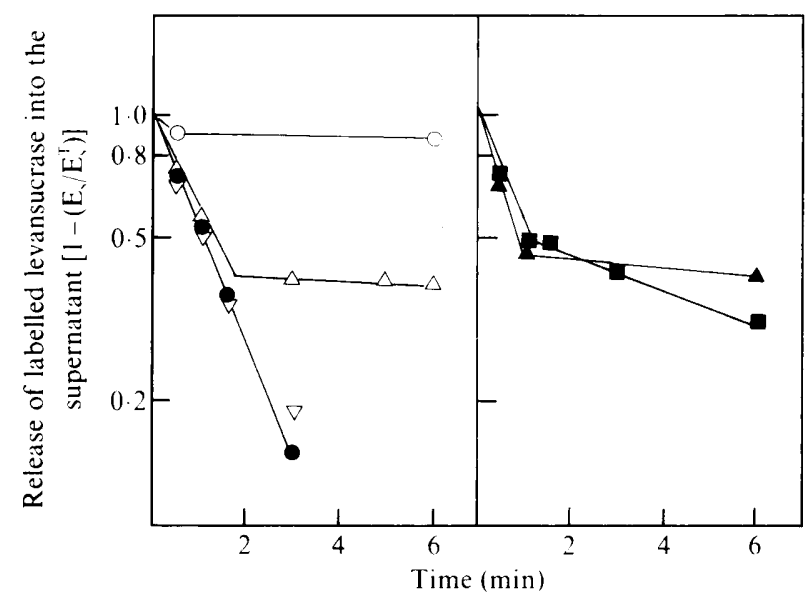

Fig. 4

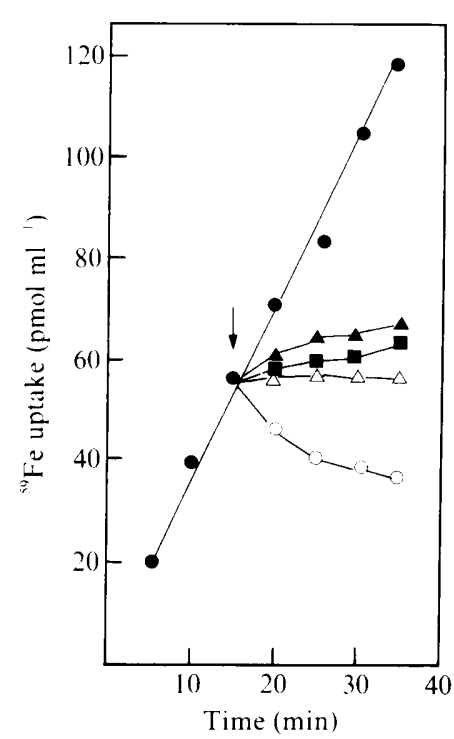

Fig. 5

Fig. 4. Effects of poisons on the release of labelled levansucrase. Bacteria in the exponential phase of growth $\left(\mathrm{OD}_{650}=1\right)$ were fully induced with $50 \mathrm{~mm}$-sucrose for $90 \mathrm{~min}$. Five $1 \mathrm{ml}$ fractions of the culture were pulse-labelled for $30 \mathrm{~s}$ with $50 \mu \mathrm{Ci}\left[{ }^{35} \mathrm{~S}\right]$ methionine. One portion was chased with $0 \cdot 1 \mathrm{ml} 0 \cdot 1 \mathrm{M}-\mathrm{non}$ radioactive methionine, each of the others was chased with the same volume of $0.1 \mathrm{M}$-methionine containing one of the poisons tested. Samples $(0.2 \mathrm{ml})$ were removed at the chase times indicated, and treated as described in Methods. Control; $\nabla$, chloramphenicol $\left(200 \mu \mathrm{g} \mathrm{ml}^{-1}\right) ; \bigcirc$, cyanide $(0 \cdot 1 \mathrm{M})$; $\triangle$, arsenate $(0 \cdot 1 \mathrm{M}) ; \mathbf{\square}, \mathrm{CCCP}(50 \mu \mathrm{M}) ; \Delta$, valinomycin $\left(20 \mu \mathrm{g} \mathrm{ml}^{-1}+0 \cdot 4 \mathrm{M}-\mathrm{KCl}\right)$.

Fig. 5. Effect of poisons on iron uptake by B. subtilis $\mathrm{QB} 112$. ${ }^{59} \mathrm{FeCl}_{3}(50 \mu \mathrm{l}$; specific activity $1 \mathrm{mCi} \mathrm{mol}^{-1}$ ) was added to $6 \mathrm{ml}$ of a cell suspension at an $\mathrm{OD}_{650}$ of 1 (final concentration of iron $=1 \mu \mathrm{M})$. Samples $(0.2 \mathrm{ml})$ were taken at intervals over a period of $15 \mathrm{~min}$ and subsequently assayed for the labelled iron incorporated. The cell suspension was then divided into fractions of $1 \mathrm{ml}$ and the poisons were added at the concentrations indicated. Samples were withdrawn at intervals from each fraction and assayed for radioactive iron. Control; $\bigcirc$, cyanide $(0 \cdot 1 \mathrm{M}) ; \triangle$, arsenate $(0 \cdot 1 \mathrm{M}) ; \mathbf{\square}$, $\mathrm{CCCP}(50 \mu \mathrm{M}) ; \Delta$, valinomycin $\left(20 \mu \mathrm{g} \mathrm{ml}^{-1}+0.4 \mathrm{M}-\mathrm{KCl}\right)$. The arrow indicates the addition of poisons to the cell suspensions.

levansucrase synthesis decreased with increasing EDTA concentration in the culture medium (Fig. 6). Levansucrase synthesis was completely stopped by 0.2 mM-EDTA. EDTA did not affect the stability or the activity of exocellular levansucrase. The reversal of EDTA action was studied by adding ferric iron, as ferri-DHB, to the culture medium, since DHB is a well-known siderophore of $\boldsymbol{B}$. subtilis (Neilands, 1982). Levansucrase production resumed in the presence of this ferrisiderophore, suggesting that ferric iron is directly involved in levansucrase production. EDTA may modulate the site of synthesis of this exocellular protein by blocking the exchange of iron between the culture medium and the cells.

Effect of EDTA on the kinetics of labelled levansucrase release during a pulse-chase experiment

The kinetics of labelled levansucrase release into the culture supernatant after chasing with non-radioactive methionine alone and in the presence of $0.2 \mathrm{~mm}$-EDTA are shown in Fig. 7 . The presence of EDTA largely inhibited the release of labelled levansucrase into the culture supernatant.

\section{Effects of EDTA on the synthesis and the accumulation of the membrane forms of levansucrase}

Immunoblot analysis was used to investigate the presence of the membrane forms of levansucrase under conditions in which EDTA inhibited the production of the protein. The 


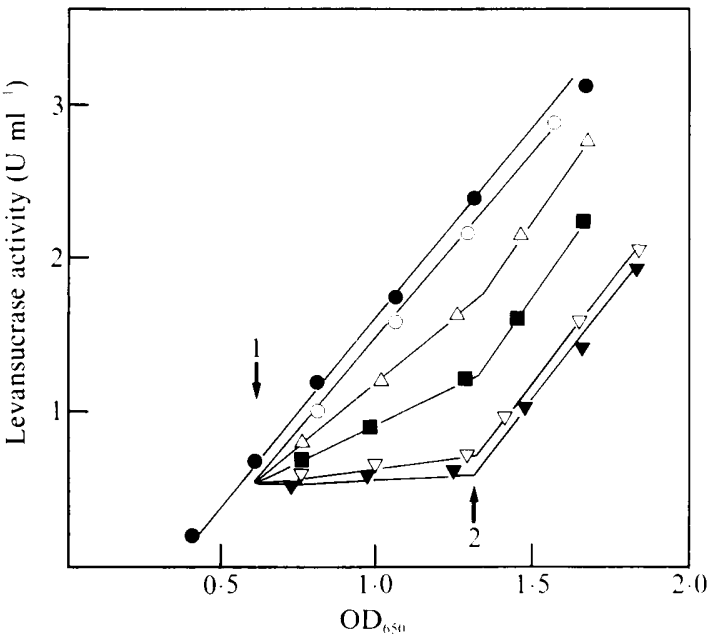

Fig. 6

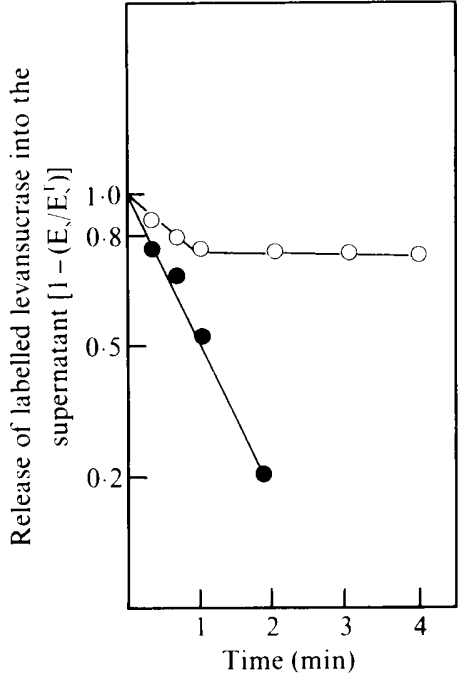

Fig. 7

Fig. 6. Levansucrase production of B. subtilis QB112 grown in the presence of EDTA in iron-deficient medium, and reversal of EDTA action. A culture at an $\mathrm{OD}_{650}$ of 0.3 was induced for levansucrase synthesis by adding $50 \mathrm{~mm}$-sucrose. After $1 \mathrm{~h}$ the culture was divided into equal portions, and each was placed in a flask containing the indicated EDTA concentration $(O$, no EDTA added; $\bigcirc, 0.01 \mathrm{mM}$ EDTA; $\triangle, 0.02 \mathrm{mM} ; \mathbf{\square}, 0.05 \mathrm{mM} ; \nabla, 0.1 \mathrm{mM} ; \triangle, 0.2 \mathrm{mM}$ ). Levansucrase was assayed as described in Methods on samples withdrawn at intervals. Arrow 1 indicates the addition of EDTA and arrow 2 the addition of ferri-DHB (0.5 mM).

Fig. 7. Effects of EDTA on the release of labelled levansucrase into the culture supernatant. Bacteria at an $\mathrm{OD}_{650}$ of 0.6 were fully induced with $50 \mathrm{~mm}$-sucrose for $90 \mathrm{~min}$. Two $1 \mathrm{ml}$ portions of the culture were pulse-labelled for $30 \mathrm{~s}$ with $50 \mu \mathrm{Ci}\left[{ }^{35} \mathrm{~S}\right]$ methionine. One portion was chased with non-radioactive methionine $(O)$; the other was chased with a solution of methionine containing EDTA (final concentration $0.2 \mathrm{mM})(\mathrm{O})$.
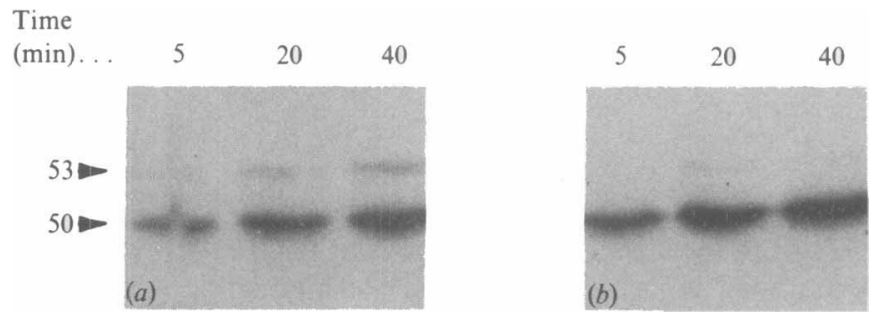

Fig. 8. Production of the cell-associated forms of levansucrase as a function of the time in $0 \cdot 2 \mathrm{~mm}$ EDTA : immunoblot obtained by analysis of the cell extracts. Bacteria at an $\mathrm{OD}_{650}$ of 1 were induced for levansucrase synthesis by adding $50 \mathrm{~mm}$-sucrose for $45 \mathrm{~min}$. The culture was divided into two: no EDTA was added to one part $(a)$ and 0.2 mM-EDTA was added to the other $(b)$. Samples were removed at the times indicated and treated as described in Methods.

results showed that the amount of the $53000 M_{\mathrm{r}}$ form was lower and that of the $50000 M_{\mathrm{r}}$ form was slightly higher than the levels in the control samples (Fig. 8). These data indicate that the $50000 M_{\mathrm{r}}$ form was not released in the presence of EDTA. The resulting inhibition of levansucrase synthesis was presumably due to the blocking of the export sites by saturation of the membrane sites. 

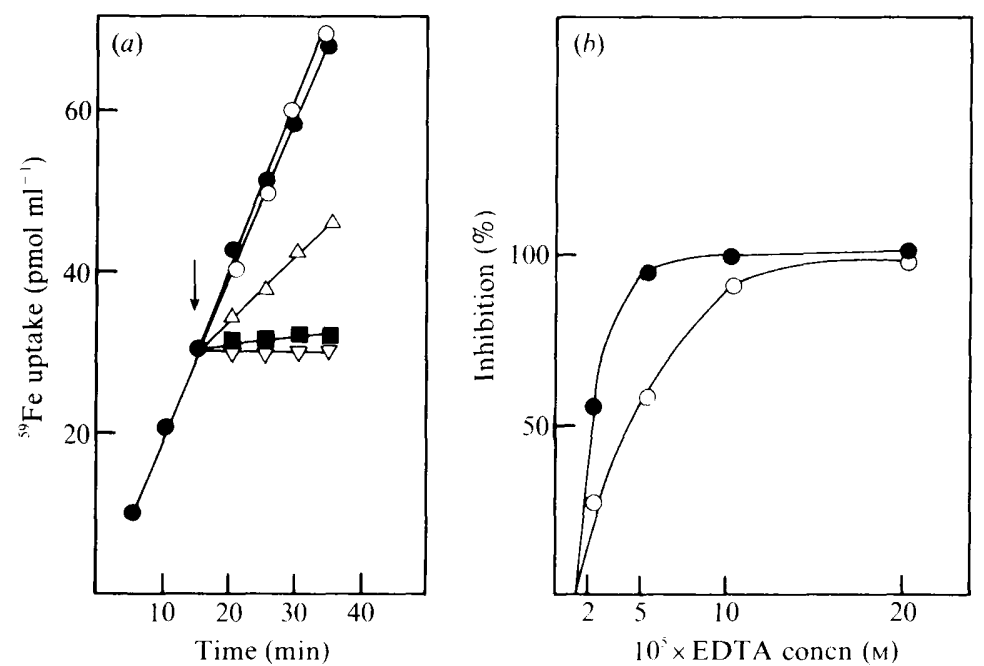

Fig. 9. Iron uptake in the presence of EDTA. (a) Iron uptake by bacteria growing in the presence of various concentrations of EDTA was measured as described in the legend of $\mathrm{Fig} .5 .{ }^{59} \mathrm{FeCl}_{3}$ $\left(50 \mu \mathrm{ml}^{-1}\right)$ was added to a cell suspension at an $\mathrm{OD}_{650}$ of 0.5 . The arrow indicates the addition of EDTA to the cell suspension at the following concentrations: $O$, no EDTA added; $0,0 \cdot 01 \mathrm{mM}^{-}$ EDTA; $\triangle, 0.02 \mathrm{~mm} ; 0.05 \mathrm{~mm} \nabla, 0.1 \mathrm{~mm}$. (b) Inhibition of iron uptake $(O)$ and of levansucrase synthesis $(O)$ as a function of EDTA concentration.

Table 1. Induction parameters of levansucrase of B. subtilis $Q B 112$ in the presence of various siderophores

Ferri-siderophore added

None

Ferridesferal ( $0.5 \mathrm{~mm})$

Ferric ammonium citrate $\left(22 \mu \mathrm{g} \mathrm{ml}^{-1}\right)$

Ferric-DHB (0.5 mM)
Differential rate of levansucrase synthesis (enzyme units per $\mathrm{OD}_{650}$ unit)

$2 \cdot 3$
$3 \cdot 1$
$3 \cdot 8$
$4 \cdot 2$

$2 \cdot 3$

$3 \cdot 8$

$4 \cdot 2$
Induction lag time $(\min )^{*}$

$42 \pm 4$

$28 \pm 3$

$25 \pm 3$

$8 \pm 1$

* The results are means \pm SD $(n=10)$.

\section{Effects of EDTA on iron uptake by $B$. subtilis $Q B 112$}

The effect of EDTA, in the same concentration range as above, on iron uptake is shown in Fig. 9(a). EDTA inhibited both iron uptake and the production of levansucrase, apparently simultaneously (Fig. $9 b$ ). This would suggest that the inhibition of levansucrase production is dependent on iron uptake by the bacteria and, hence, that iron is essential for the functioning of the membrane export machinery for levansucrase. These data suggested the hypothesis that the second step of levansucrase translocation is intimately related to the entrance flux of iron in the cell. We therefore attempted to ascertain which soluble form of iron produced maximum stimulation of this hypothetical machinery, when added to the culture medium.

\section{Induction pattern of levansucrase of $B$. subtilis $Q B 112$ grown in the presence of various ferrisiderophores}

The differential rate of levansucrase synthesis and the induction lag time were determined as described previously (Chambert \& Petit-Glatron, 1984) for B. subtilis QB112 grown in the presence of various ferrisiderophores. The most striking observation was the difference in the induction lag period between the treatments (Table 1). In the absence of ferrisiderophore, the 
cells responded slowly to the inducer $(42 \mathrm{~min}$ ), whereas the lag period was only $8 \mathrm{~min}$ in the presence of ferri-DHB. Levansucrase production was also slightly higher in the presence of ferriDHB than in the presence of ferric ammonium citrate, the soluble form of iron usually added to the culture medium of $B$. subtilis.

\section{DISCUSSION}

Pulse-chase experiments with a $B$. subtilis strain that hyperproduces levansucrase provide a convenient way of experimentally dissociating the two steps of the membrane translocation of this enzyme. The kinetics of the second step can be readily analysed, and the results presented indicate that it is an active, energy-requiring, process which may require the continuous uptake of ferric iron by the bacteria. While our data do not show that these dynamic events are strictly coupled, it remains an attractive hypothesis. The main argument against such a conclusion is that only iron transport was studied, although the various inhibitors used may also inhibit the transport of other metals. However, the reversal of EDTA inhibition by ferri-DHB and the modulation of the levansucrase induction pattern by various forms of soluble iron clearly indicate that iron plays a specific and fundamental role in the secretion process of levansucrase.

How may iron be involved in the process? Iron has never been found in close association with the purified exocellular enzyme (Lebrun \& Van Rapenbusch, 1980), and levansucrase does not seem to possess sequences that are potential iron-binding domains (Berg, 1986). However, a soluble iron complex can induce tetramerization of the protein (Delobbe, 1968). Six to eight atoms of iron are associated with the tetramer; the metal-protein affinity constant is low $\left(3 \times 10^{4} \mathrm{M}^{-1}\right)$. Such a structure increases the thermostability of the enzyme. Recently Grof $e t a l$. (1988), from vibrational Raman spectroscopy studies, have shown that the presence of ferric

iron considerably increases the ordered helical structure of levansucrase and modifies the environment of the tryptophan and phenylalanine residues. Finally, both transient membrane forms of levansucrase are enzymically active only in the presence of ferric iron complex (PetitGlatron et al., 1987). We have therefore adopted as a working hypothesis the concept that during export, levansucrase undergoes a conformational change in which iron plays an important role.

Several recent reports have described the role of folding in protein transport in prokaryote (Freudl et al., 1986; Randall \& Hardy, 1986) and in eukaryote systems (Kreis \& Lodish, 1986; Gething et al., 1986). These conformational changes involved all three levels of protein organization, i.e. secondary, tertiary and quaternary structures. Iron may be a cofactor in an autocatalytic mechanism leading to sequential folding of the levansucrase polypeptide chain, which is required for the translocation of successive folded subdomains of the protein across the membrane (Maher \& Singer, 1986). If a transient tetramer were formed, it should have characteristic chemical cross-linking (Baskin \& Yang, 1982). It is also possible, in view of the induction lag period of levansucrase synthesis, that the export machinery for the protein involves the assembly of several cellular components. Finally, Le Coq et al. (1984) have shown that mutational alterations affecting the bacterium's ability to export levansucrase are localized in the second half of the structural gene. Such mutations may be most useful as a tool with which to study the molecular mechanism of the second step of levansucrase translocation. The location and the nature of the genetic alteration in these mutants are presently being studied in our laboratory.

\section{REFERENCES}

Avrameas, S. \& Ternynck, T. (1969). The crosslinking of proteins with glutaraldehyde and its use for the preparation of immunoadsorbents. Immunochemistry 6, 53-65.

Baskin, L. \& YANG, C. S. (1982). Cross-linking studies of the protein topography of rat liver microsomes. Biochimica et biophysica acta 684, 263-271.

Benyahia, F. \& Petit-Glatron, M. F. (1985). Preferential synthesis, localisation and solubilisation of a precursor form of Bacillus subtilis levansucrase in an Escherichia coli minicell system. FEMS Microbiology Letters 30, 155-160.

Berg, J. (1986). Potential metal-binding domains in nucleic acid binding proteins. Science 242, 485-486.

BRADFORD, M. M. (1976). A rapid and sensitive method for the quantitation of microgram quantities of protein utilizing the principle of protein-dye binding. Analytical Biochemistry 72, 248-254. 
BURNETTE, W. N. (1981). "Western blotting": electrophoresis transfer of proteins from sodium dodecyl sulfate-polyacrylamide gels to unmodified nitrocellulose and radiographic detection with antibody and radioiodinated protein A. Analytical Biochemistry 112, 195-203.

Chambert, R. \& Gonzy-Treboul, G. (1976). Levansucrase of Bacillus subtilis. Characterization of a stabilized fructosyl-enzyme complex and identification of an aspartyl residue as the binding site of the fructosyl group. European Journal of Biochemistry 71, 493-508.

Chambert, R. \& Petit-Glatron, M. F. (1984). Hyperproduction of exocellular levansucrase by Bacillus subtilis: examination of the phenotype of a sac $U^{\mathrm{h}}$ strain. Journal of General Microbiology 130, 3143-3152.

DEDONDER, R. (1966). Levansucrase from Bacillus subtilis. Methods in Enzymology 8, 500-506.

Delobbe, A. (1968). Le rôle de fer dans la production, la purification de la lévane-sucrase. Effets sur l'enzyme purifié. Bulletin de la Société de chimie biologique 50, 641-673.

Freudl, R., SchWartz, H., Stierhof, Y. D., Gamon, K., Hindennach, I. \& HenNing, U. (1986). An outer membrane protein (OmpA) of Escherichia coli $\mathrm{K} 12$ undergoes a conformational change during export. Journal of Biological Chemistry 261, 11355-11361.

Gething, M. J., McCammon, K. \& Sambrook, J. (1986). Expression of wild-type and mutant forms of influenza hemagglutinin: the role of folding in intracellular transport. Cell 46, 939-950.

Grof, P., Aslanian, D. \& Chambert, R. (1988). Raman spectroscopic study of Bacillus subtilis extracellular levansucrase; effects of ferric ions on the protein conformation. Journal of Raman Spectroscopy (in the press).

Himeno, T., Imanaka, T. \& Aiba, S. (1986). Protein secretion in Bacillus subtilis as influenced by the combination of signal sequence and the following mature portion. FEMS Microbiology Letters 35, 1721.

Joliffe, L. K., Doyle, R. J. \& Streips, U. N. (1981). The energized membrane and cellular autolysis in Bacillus subtilis. Cell. 25, 753-763.

KREIS, T. E. \& LoDISH, H. F. (1986). Oligomerization is essential for transport of vesicular stomatitis viral glycoprotein to the cell surface. Cell 46, 929-937.

Kunst, F., Pascal, M., Lepesant-Kejzlarova, J., Lepesant, J. A., Billault, A. \& Dedonder, R. (1974). Pleiotropic mutations affecting sporulation conditions and the syntheses of extracellular en- zymes in Bacillus subtilis 168. Biochimie 56, 14811489.

LAEMMLI, U. K. (1970). Cleavage of structural proteins during the assembly of the head of bacteriophage T4. Nature, London 227, 680-685.

Lebrun, E. \& VAN Rapenbusch, R. (1980). The structure of Bacillus subtilis levansucrase at $3.8 \AA$ resolution. Journal of Biological Chemistry 255, 12034-12036.

Le CoQ, D., Ratet, P., Steinmetz, M. \& Gay, P. (1984). A genetic approach to levansucrase secretion in Bacillus subtilis. In Genetics and Biotechnology of Bacilli, pp. 141-152. Edited by A. T. Ganesan \& J. A. Hoch. New York: Academic Press.

Maher, P. A. \& Singer, S. J. (1986). Disulfide bonds and the translocation of proteins across membranes. Proceedings of the National Academy of Sciences of the United States of America 83, 9001-9005.

NeILANDS, J. B. (1982). Microbial envelope proteins related to iron. Annual Review of Microbiology 36, 285-309.

Peters, W. J. \& Warren, R. A. J. (1970). The mechanism of iron uptake in Bacillus subtilis. Canadian Journal of Microbiology 16, 1285-1291.

Petit-Glatron, M. F., Chambert, R. \& Steinmetz, M. (1980). Levansucrase of Bacillus subtilis: characterization of a form isolated from phenol treated cells and activated by Triton X-100. European Journal of Biochemistry 103, 189-195.

Petit-Glatron, M. F., Benyahia, F. \& Chambert, R. (1987). Secretion of Bacillus subtilis levansucrase: a possible two-step mechanism. European Journal of Biochemistry 163, 379-387.

RANDALl, L. \& HaRdy, S. J. S. (1986). Correlation of competence for export with lack of tertiary structure of the mature species: a study in vivo of maltosebinding protein in $E$. coli. Cell 46, 921-928.

Rothman, J. E. \& KornberG, R. D. (1986). An unfolding story of protein translocation. Nature, London 322, 209-210.

Smith, H., Bron, S., Van Ee, J. \& Venema, G. (1987). Construction and use of signal sequence selection vectors in Escherichia coli and Bacillus subtilis. Journal of Bacteriology 169, 3321-3328.

Tangeras, A., Flatmark, T., Backstrom, D. \& EHRENBERG, A. (1980). Mitochondrial iron not bound in heme and iron sulfur centers, estimation, compartmentation and redox state. Biochimica et biophysica acta 589, 162-175.

WiCKNER, W. T. \& Lodish, H. F. (1985). Multiple mechanisms of protein insertion into and across membranes. Science 230, 400-407. 